\title{
Constituents of Encyclia longifolia Schltr. (Orchidaceae)
}

\author{
Jnanabrata Bhattacharyya $^{1^{*}}$, Abdumalik A. Nishonov ${ }^{1}$, Leonardo Pessoa Felix ${ }^{2}$, \\ Maria F.O. Pires ${ }^{3}$, George M. Majetich ${ }^{1}$ \\ ${ }^{1}$ Department of Chemistry, University of Georgia, Athens, GA 30605, USA, \\ ${ }^{2}$ Departamento de Fitociencia, UFPB, 58397-000, Areia, PB, Brazil, \\ ${ }^{3}$ Centro de Ciências Biológicas e Agrárias, Universidade Estadual do Piauí, Rua João Cabral s/n, \\ Caixa-Postal 381, Pirajá, 64002-150, Teresina, PI, Brazil
}

\begin{abstract}
RESUMO: "Constituintes de Encyclia longifolia Schltr. (Orchidaceae)". Uma análise química detalhada dos metabólitos secundários não voláteis de Encyclia longifolia Schltr. Sin. Epidendrum longifolium Barb. Rodr. foi realizada na tentativa de prestar suporte quimiotaxonômico para a recente separação do gênero Encyclia em Encyclia Hook e Prosthechea Knowles \& Westc.
\end{abstract}

Unitermos: Encyclia longifolia, Orchidaceae, Prosthechea, 9,10-diidrofenantreno.

\begin{abstract}
A detailed chemical analysis of the non-volatile secondary metabolites of Encyclia longifolia Schltr. syn. Epidendrum longifolium Barb. Rodr. was carried out in an attempt to lend a chemotaxonomic support for the recent separation of the genus Encyclia into Encyclia Hook and Prosthechea Knowles \& Westc.
\end{abstract}

Keywords: Encyclia longifolia, Orchidaceae, Prosthechea, 9, 10-dihydrophenanthrene.

\section{INTRODUCTION}

The genus Encyclia Hook belongs to the sub tribe Laeliinae of the family Orchidaceae. There has been much controversy regarding the taxonomic group to which the genus Encycla belongs which led to the recent delimitation of the genus into Encyclia Hook and Prosthechea Knowles \& Westc. (Higgins, 1997). Traditionally, the genus Encyclia consisted of about 250 species which also included Prosthechea. Encyclia and Prosthechea were either considered congenerics (Dressler, 1993), or Prosthechea had been treated under different epithets such as Anacheilium (Pabst et al., 1981) and Hormidium Lindl. Ex Heynh. (Brieger; Hunt, 1969). Most recently, the genera Encyclia and Prosthechea were separated initially on the basis of morphological characteristics which also justified the inclusion of Anacheilium and Hormidium in the latter (Higgins, 1997). Subsequent molecular genetic studies supported this separation and suggested a closer relationship of Prosthechea with Cattleya Lindl rather than Encyclia (van den Berg, 2000). The most recent study (Oliveira Pires et al., 2003) on the anatomical features of several Encyclia and Prosthechea species lent ample support to their separation. In this study, the presence of so-called "flavonoid crystals", typical of Prosthechea species (Pabst et al., 1981; Higgins, 1997) were not observed in the various species of Encyclia including E. longifolia.

We have initiated a chemical investigation to isolate and characterize the non-volatile secondary metabolites of several species of Encyclia and Prosthechea in an attempt to identify any characteristic chemical markers in support of their recent taxonomic separation. To our knowledge, other than some preliminary qualitative detection of alkaloids (Luning, 1964), some unidentified flavone-C-glycosides (Williams, 1979) and volatile substances (Kaiser, 1993), no report on the isolation and characterization of any non-volatile secondary metabolite of E. longifolia has appeared in the literature, so far. This communication describes the preliminary results of the isolation and characterization of non-volatile constituents of Encyclia longifolia Schltr. syn. Epidendrum longifolium Barb. Rodr.

\section{MATERIAL AND METHODS}

\section{Plant material}

Encyclia longifolia Schltr. syn. Epidendrum longifolium Barb. Rodr grows throughout the tropical Americas especially in the eastern coastal areas of Brazil. The plant material used in the present study was collected in November 2001 from the dunes of Natal, Rio Grande do Norte, identified by Prof. Leonardo Felix, Departamento de Fitociencia, UFPB, Areia, Brazil and the herbarium specimen (L. P. Felix 8960) is deposited at the EAN Herbarium of UFPB, Areia, Brazil. 


\section{Extraction, isolation and identification}

The aerial part of E. longifolia was extracted with $90 \%$ aqueous EtOH. The extract was concentrated in vacuo. The residue upon $\mathrm{CC}$ on silica gel using $\mathrm{CHCl}_{3}$ $\mathrm{CH}_{3} \mathrm{OH}$ with increasing amounts of $\mathrm{CH}_{3} \mathrm{OH}$ followed by $\mathrm{CH}_{3} \mathrm{OH}$ with increasing amounts of $\mathrm{H}_{2} \mathrm{O}$ as eluants resulted in the isolation of 4,7-dihydroxy-2-methoxy9,10-dihydrophenanthrene (Majumdar et al., 1990), vitexin (Evans et al., 1957), 4-hydroxybenzoic acid, $\beta$-D-glucopyranosyl-4-hydroxybenzoic acid, gastrodin (Taguchi et al., 1981), 4-hydroxybenzaldehyde, 4-O$\beta$-D-glucosylbenzylalcohol, sucrose, glucose and yet unidentified compounds, $\mathrm{C}_{9} \mathrm{H}_{8} \mathrm{O}_{3}$ and a trisaccharide. The identification of all the compounds were done with the aid of the comparison of physical characteristics and spectroscopic data (mp, IR, EIMS, and ${ }^{1} \mathrm{H}$ and ${ }^{13} \mathrm{C}$ NMR) with those given in the literature.

\section{RESULTS AND DISCUSSION}

To our knowledge, this is the first report of the isolation and characterization of any non-volatile secondary metabolites of a species of Encylia. Among the isolated constituents (vide infra), the presence of $p$ hydroxybenzoic acid and benzoic acid derivatives are widespread in Orchidaceae (Bates-Smith, 1968). Also, flavone-C-glucoside, vitexin has been encountered in various species of Orchidaceae (Williams, 1979) and a few other species outside of Laeliinae yielded 9,10dihydrophenanthrenes (Majumdar; Banerjee, 1990). That leaves benzadehyde and benzyl alcohol as constituents yet to be isolated from Encyclia and/or Prosthechea species. Further study is in progress.

\section{ACKNOWLEDGEMENTS}

JB is grateful to CAPES for the award of a generous fellowship for visiting professor. The authors wish to thank Prof. Maria de Fatima Agra, Head of the Botany section for her help and interest and Ms. Dulce Goncalves da Oliveira for her technical assistance, both of UFPB, João Pessoa, PB. Brazil.

\section{REFERENCES}

Bates-Smith EC 1968. The phenolic constituents of the plants and their taxonomic significance 2. Monocotyledons. J Linn Soc London (Botany) 60: 325-356.

Brieger FG, Hunt PF 1969. Hormidium, Maxillaria and Scaphyglotis (Orch.). Taxon 18: 601-603.

Dressler RL 1993. Phylogeny and Classification of the Orchid Family. Dioscorides Press, Portland, U.S.A.

Evans WH, McGookin A, Jurd L, Robertson A, Williamson WRN 1957. Vitexin I. J Chem Soc 3510-3523.

Higgins WE 1997. A reconsideration of the genus Prosthechea (Orchdaceae). Phytologia 82: 370-383.

Kaiser R. 1993. The scent of orchids, olfactory and chemical investigations. Editiones Roche. Basel.

Luning B. 1964. Studies on Orchidaceae Alkaloids I. Screening of species for Alkaloids 1. Acta Chim Scand 18: 1507-1516.

Majumdar PL, Lahiri S. 1990. Lusianthin and lucianthridin, two stibenoids from the orchid Lusia individa. Phytochemistry 29: 621-624.

Majumdar PL, Banerjee S 1990. Two stibenoids from the orchid Eria flava. Phytochemistry 29: 3052-3055.

Oliveira Pires MF, Semir J, Melo de Pinna GFA, Felix L. 2003. Taxonomic separation of the genera Prosthechea and Encyclia (Liliinae Orchidaceae) using leaf and root anatomical features. Bot J Linn Soc 143: 293303.

Pabst GGJ, Moutinho JL, Pinto AV 1981. An attempt to establish the correct statement for genus Anachelium Hoffmgg and revision of the genus Hormidium Lindl. Ex Heynh. Bradea 3: 173-186.

Taguchi H,Yosioka I, Yamasaki K, Kim IH 1981. Studies on the constituents of Gastrodia elata Blume. Chem Pharm Bull 29: 55-62.

Van der Berg, C, Higgins WE, Dressler RL, Whitten WM, Arena MAS, Culham A, Chase MW 2000. A phylogenic analysis of Laeliinae subgroups with Orchdaceae based on sequence data from internal transcribed spacers (Its) of nuclear ribosomal DNA. Lindleyana 15: 96-114.

Williams, C. A. 1979. The leaf flavonoides of Orchidaceae. Phytochemistry 18: 803-813.

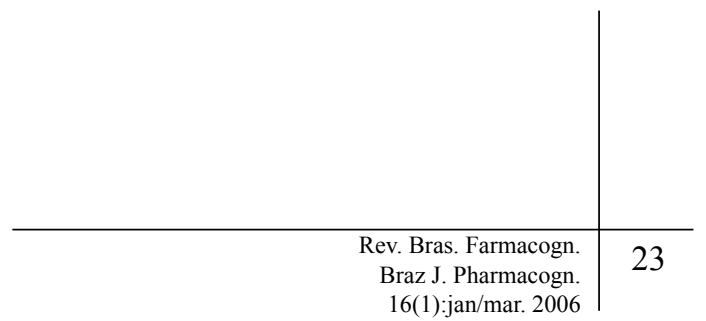

